Int. J. Odontostomat., 10(1):11-16, 2016.

\title{
Epidemiological Profile and Characterization of Oral and Maxillofacial injuries in Women Victims of Interpersonal Violence
}

\author{
Perfil Epidemiológico y Caracterización de las Lesiones Orales y Maxilofaciales en \\ Mujeres Víctimas de Violencia Interpersonal
}

\begin{abstract}
Elane Nery da Silva*; Felipe Rafael Rios Oliveira Matos*; Rodolfo Macedo Cruz Pimenta*; Jose Lucas Sani de Alcantara Rodrigues ${ }^{* *}$; Jeidson Antônio Morais Marques ${ }^{* * *}$; Jamilly de Oliveira Musse ${ }^{* * *}$ \& Luiz Renato Paranhos ${ }^{* \star *}$
\end{abstract}

DA SILVA, E. N.; MATOS, F. R. R. O.; PIMENTA, R. M. C.; RODRIGUES, J. L. S. D.; MARQUES, J. A. M.; MUSSE, J. D. \& PARANHOS, L. R. Epidemiological profile and characterization of oral and maxillofacial injuries in women victims of interpersonal violence. Int. J. Odontostomat., 10(1):11-16, 2016.

ABSTRACT: The objective of this study was to determine the epidemiological profile of women victims of violence and characterize the injuries affecting their maxillofacial region. This was an analytic study using secondary data from 470 expert reports of domestic violence involving women, collected from January 2007 to December 2011 in the Department of Dentistry of the Institute of Legal Medicine in the city of Feira de Santana, Bahia, Brazil. The majority of the examined women were Afro-caucasian (72.6\%), single (74.9\%), and with mean age of 30.4 years. The buccal (51\%) and orbital (8.8 $\%)$ regions were the most affected extraoral sites. As to the oral cavity, the most affected sites were teeth (50.8 \%) and the lip mucosa (35\%). In most cases the lesions against women were associated with an aggressor having a close relationship with the victim. The most prevalent lesions were edema; fracture; tooth dislocation; and bruise. These findings can subsidize the development of policies to prevent violence against women, and for public safety.

KEY WORDS: domestic violence, violence against women, facial injuries, forensic dentistry.

\section{INTRODUCTION}

Violence is a Public Health problem of great magnitude that causes strong impact in the population regarding morbidity and mortality (Roselino et al., 2009; Secretaria de Política de Saúde, 2000). It is a social problem that is increasing in frequency and severity over the past years (Garbin et al., 2008; Santi et al., 2005). Their etiologies are, mainly, traffic accidents, falls, interpersonal violence, and those arising from professional activities and practice of sports. The variables observed were amplitude, type and location of the injury. The head and neck region was the most affected (Deslandes et al., 2000; Schraiber et al., 2002) and the one that requires attention, because of its importance in social life and interpersonal relations (Roselino et al.; Krause et al., 2004; Montovani et al., 2006).
Women are the individuals for whom interpersonal violence has gained significant notoriety, and, since the nineties, according to the Pan American Health Organization (PAHO), violence acquires an endemic character, so the realization of the damages inflicted is essential to Dentistry (Cavalcanti, 2006; Chiaperini et al., 2009; Nedel et al., 2009).

Accordingly, works (Garbin et al., 2006; Rezende et al., 2007; Santana et al., 2011; Silva, 2003) are being carried out in different contexts, in order to describe the epidemiological and social aspects of violence against women, as well as to generate interesting information to health. Therefore, the present study was aimed at establishing an epidemiological profile of battered victims, besides characterizing the elapsed

\footnotetext{
DDS, Private Office, Feira de Santana, Bahía, Brazil.

** DDS Undergraduate, Department of Dentistry, Federal University of Sergipe, Lagarto, Brazil.

${ }^{* * *}$ DDS, MSc, PhD, Professor, State University of Feira de Santana, Department of Health, Feira de Santana, Bahía, Brazil.

${ }^{* *+*}$ DDS, MSc, PhD, Professor, Department of Dentistry, Federal University of Sergipe, Lagarto, Brazil.
} 
DA SILVA, E. N.; MATOS, F. R. R. O.; PIMENTA, R. M. C.; RODRIGUES, J. L. S. D.; MARQUES, J. A. M.; MUSSE, J. D. \& PARANHOS, L. R. Epidemiological profile and characterization of oral and maxillofacial injuries in women victims of interpersonal violence. Int. J. Odontostomat., 10(1):11-16, 2016.

injuries of interpersonal violence that affected the Oral and Maxillofacial region of women victims of violence.

\section{MATERIAL AND METHOD}

This study was approved by the Ethics Committee in Research of the Universidade Estadual de Feira de Santana (State University of Feira de Santana) - (protocol \# 092/2010), ensuring that ethical and legal principles were followed.

Type of Study and sample characterization. It is an analytical observational study of secondary data, in which 470 expert testimonies of living people were evaluated, collected in the period from January 2007 to December 2011, in the Dentistry sector of the Instituto Médico Legal (IML) de Feira de Santana, BA (Legal Medical Institute of Feira de Santana, BA), Brazil. The state had an estimated population of $15,126,371$ inhabitants in 2014, according to the (Instituto Brasileiro de Geografia e Estatística, 2010), with an area of $564,733.177 \mathrm{~km}^{2}$ possessing 470 municipalities, among them, the city of Feira de Santana with an approximate population of 416 inhabitants per square kilometer.

We excluded expert testimonies related to males, expert testimonies with incomplete data or situations in which the requests for personal injury exam were not performed and, the cases in which the victims died. The eligibility criteria were expert testimonies that resulted from domestic violence, being the primary outcome, the presence of Oral and maxillofacial injuries. The information contained in the reports, such as age, skin color, place of birth, nationality, marital status, occupation and residence; victim's relationship with the aggressor; characterization of the instrument used (piercing, cutting, blunt and possible combinations); description of the injuries and the location (intra- and extra-oral) was transcribed to a elaborated record for the referred research.

Data analysis. The statistical analysis was performed by using the Statistical Package for Social Science Program for Windows SPSS, version 11.0, after the collection and tabulation of data. The prevalence of Oral and maxillofacial injuries was calculated with all the medical records analyzed, moreover, facing the dichotomous variables, the prevalence ratios and their confidence intervals of $95 \%$ was estimated.

\section{RESULTS}

Over the five years of investigation in this study, it was issued, by the Dentistry sector of the Instituto Médico Legal (IML) of Feira de Santana, BA, Brazil, 470 expert testimonies performed with living people, in which, only 223 were eligible, representing $47.5 \%$ of the forensic examinations performed.

Table I shows the characterization of the social profile of women who had been through forensic medical examination in the IML. Table II shows the emotional and/or marital bond between the victims and the aggressor. The nature of the instrument used against women, as well as the type of injury, is shown in Tables III and IV, respectively.

The injuries were found in various intra- and extra-oral regions (Table $\mathrm{V}$ ). Regarding the extra-oral location, the buccal region was the most affected (51 $\%$ of cases; $n=99)$, followed by the orbital region ( 8.8 $\%)$ and the malar region (5.2\%). The least affected regions were the infraorbital $(0.5 \%)$, temporal $(1.6 \%)$

Table I. Characterization of the social profile of women that underwent forensic examination in the IML in Feira de Santana, Bahia, Brazil, from 2007 to 2011.

\begin{tabular}{|c|c|c|c|}
\hline & & $\mathbf{n}$ & $\%$ \\
\hline \multirow[t]{6}{*}{ Age Group } & $0-11$ & 6 & 2.7 \\
\hline & $12-17$ & 21 & 9.4 \\
\hline & $18-35$ & 128 & 57.4 \\
\hline & $36-59$ & 64 & 28.7 \\
\hline & $\geq 60$ & 4 & 1.8 \\
\hline & Total & 223 & 100 \\
\hline \multirow[t]{5}{*}{ Ethnic Group } & Caucasian & 11 & 4.9 \\
\hline & Afro-Descendants & 48 & 21.6 \\
\hline & Afro-Caucasian & 162 & 72.6 \\
\hline & Not Reported & 2 & 0.9 \\
\hline & Total & 223 & 100 \\
\hline \multirow[t]{6}{*}{ Marital Status } & Single & 167 & 74.9 \\
\hline & Married & 34 & 15.2 \\
\hline & Divorced & 4 & 1.8 \\
\hline & Widow & 4 & 1.8 \\
\hline & Not Reported & 14 & 6.3 \\
\hline & Total & 223 & 100 \\
\hline \multirow[t]{7}{*}{ Occupation } & Student & 42 & 18.8 \\
\hline & Maid & 38 & 17 \\
\hline & Farmer & 20 & 9 \\
\hline & Housewife & 17 & 7.6 \\
\hline & Other & 90 & 40.4 \\
\hline & Not Reported & 16 & 7.2 \\
\hline & Total & 223 & 100 \\
\hline
\end{tabular}

Source: IML of Feira de Santana, BA, Brazil. 
and maxillary $(2.1 \%)$. Teeth and lip mucosa were the most affected structures in the oral cavity, with $50.8 \%$ and $35 \%$, respectively. Jugal mucosa, gingiva, alveolar mucosa, alveolar ridge, hard palate, tongue and floor of mouth suffered somewhat from the aggressions, accounting for $13.2 \%$ of the occurrences.
Table II. Bond of women that were subject to forensic examination with the aggressor, Feira de Santana, Bahia, Brazil, from 2007 to 2011.

\begin{tabular}{lcc}
\hline Bond & $\mathbf{n}$ & $\mathbf{\%}$ \\
\hline Father/Mother & 1 & 0.4 \\
Brother/Sister & 4 & 1.8 \\
Nephew/Niece & 2 & 0.9 \\
Cousin & 1 & 0.4 \\
Son/Daughter & 1 & 0.4 \\
Spouse/Companion/husband/boyfriend & 50 & 22.5 \\
Ex- Spouse/Companion/husband/boyfriend & 34 & 15.2 \\
Other & 12 & 5.4 \\
Not Informed & 118 & 53 \\
Total & 223 & 100
\end{tabular}

Table III. Nature of the instrument used against women, Feira de Santana, Bahia, Brazil, from 2007 to 2011.

\begin{tabular}{lcc}
\hline Instrument & $\mathbf{n}$ & $\mathbf{\%}$ \\
\hline Blunt & 203 & 91 \\
Chop & 11 & 5 \\
Piercing & 1 & 0.4 \\
Cutting & 2 & 0.9 \\
Not Reported & 6 & 2.7 \\
Total & 223 & 100 \\
\hline Source: IML f Feira
\end{tabular}

Source: IML of Feira de Santana, BA, Brazil.
Table IV. Types of injuries in the Oral and maxillofacial region in women that underwent forensic investigation in the IML of Feira de Santana, Bahia, Brazil, from 2007 to 2011.

\begin{tabular}{lll}
\hline Injury Types & $\mathbf{n}$ & $\mathbf{\%}$ \\
\hline Edema & 64 & 14,4 \\
Dental Fracture & 54 & 12,2 \\
Dental Dislocation & 43 & 9,7 \\
Ecchymosis & 40 & 9 \\
Chop Wound & 39 & 8,8 \\
Blunt Wound & 30 & 6,8 \\
Incised Wound & 25 & 5,6 \\
Excoriation & 21 & 4,7 \\
Mouth opening limitation & 20 & 4,5 \\
Hematoma & 18 & 4 \\
Ulcer & 16 & 3,6 \\
Absence & 14 & 3,2 \\
Bone Fracture & 11 & 2,5 \\
Dental Avulsion & 10 & 2,2 \\
Temporomandibular Joint Problems & 7 & 1,6 \\
Deviation during Mandibular & 4 & 0,9 \\
Opening / Closing & & \\
Dental Discoloration & 2 & 0,4 \\
Other & 26 & 5,9 \\
Total & $\mathbf{4 4 4}$ & $\mathbf{1 0 0}$ \\
\hline
\end{tabular}

Source: IML of Feira de Santana, BA, Brazil.

\section{DISCUSSION}

Violence against women, especially in the facial region, is a political and social problem and something the civil and scientific society could not ignore, because the implications of this phenomenon are reflected in imbalances of all social spheres, particularly in economy,
Table V. Intra- and extra-oral location of the injuries in women that underwent forensic examination in the IML of Feira de Santana, Bahia, Brazil, from 2007 to 2011.

\begin{tabular}{llcc}
\hline & & $\mathbf{n}$ & $\%$ \\
\hline Extra-Oral & Buccal Region & 99 & 51 \\
Localization & Orbital Region & 17 & 8.8 \\
& Zigomatic Region & 10 & 5.2 \\
& Mandibular Region & 9 & 4.6 \\
& Zygomatic Region & 8 & 4.1 \\
& Buccinator Region & 8 & 4.1 \\
& Nasal Region & 8 & 4.1 \\
& Mental Region & 6 & 3.1 \\
& Parotid-masseteric Region & 5 & 2.6 \\
& Maxillary Region & 4 & 2.1 \\
& Temporal Region & 3 & 1.6 \\
& Infraorbital Region & 1 & 0.5 \\
& Other & 16 & 8.2 \\
& Total & 194 & 100 \\
Localization & Teeth & 100 & 50.8 \\
& Labial Mucosa & 69 & 35 \\
& Jugal Mucosa & 10 & 5.1 \\
& Gingiva & 9 & 4.6 \\
& Alveolar Mucosa & 2 & 1 \\
& Alveolar Ridge & 2 & 1 \\
& Hard Palate & 1 & 0.5 \\
& Tongue & 1 & 0.5 \\
& Floor of the Mouth & 1 & 0.5 \\
& Other & 2 & 1 \\
& Total & 197 & 100
\end{tabular}

Source: IML of Feira de Santana, BA, Brazil.

emotions and family (Chiaperini et al.; Nedel et al.; Santana et al.). The dental surgeon may be the professional responsible for the perception of violence cases, because most injuries occur in the Oral and maxillofacial region - the domain area of this professional 
- but training and education are needed to act on the prevention and recovery of victims of violence (Silva et al., 2014).

The data collection source and the quality of the information obtained are factors that can provide more precise knowledge of the situation of violence of the target group of the research (Rezende et al.). Thus, this study aimed to reveal the scenario of violence against women in the reality of Feira de Santana and region, with the data collection place being the Dentistry section of the IML, which is the agency in charge of performing the forensic dental examinations in the region.

In this study, 470 expert testimonies were analyzed, which revealed the predominance of males who had been subject of forensic medical examination, with $52.5 \%$ of the procedures performed $(n=247)$, compared to females ( $n=223$ ), with $47.5 \%$ of all. These results agree with those of other similar studies that evaluated violence against children, teenagers, men and women (Roselino et al.; Chiaperini et al.; Costa et al., 2007; Silveira et al., 2005). However, a research about abuse of children and adolescents showed opposite results, with $56.1 \%$ victims of the female sex (Carvalho et al., 2009).

The classification used for the age groups in this research was based on the (Câmara dos Deputados, 2012) and the study from Reis \& Fradique (2003). Among the wide variety of ages, ranging between 2 and 69 years old, the predominant age group aged between 18 and 35 years old $(n=128)$, totaling about $57.4 \%$ of the entire sample. Despite the different age groups, several authors indicate that individuals in adulthood are the ones who suffer most from effects of violence (Roselino et al.; Deslandes et al.; Chiaperini et al.; Ogundare et al., 2003; Wulkan et al., 2005). Specific studies of the female population subjected to forensic examination in IML confirm this statement. In works carried out in different Brazilian cities, such as Belo Horizonte (Rezende et al.), Ribeirão Preto (Chiaperini, et al.) and Recife (Santana et al.), the predominant age groups were 20-39 years old, 26-30 years old and 20-64 years old, respectively, which confirms the fact that adulthood is more prevalent in women victims of violence, as in the general population. Some variation was found in the study conducted by Garbin et al. (2006) (Nedel et al.), which differs profoundly from the evidence found in this study, since the authors concluded that most of the victims of domestic violence were children and adolescents aging from 0 to 15 years old. However, this report only considers domestic violence, opposed to this work that analyses other etiologies. The average age was 30.4 years old, which corroborates the study of (Rezende et al.), that calculated an average of 30.3 years old (results a little distant of the averages of 28 and 29.9 years old defined by (Chiaperini et al.) and (Santana et al.) respectively.

Among the sociodemographic information related to the ethnic groups, most of the women that were subject of forensic medical examination were Afro-Caucasians ( $n=162$ or $72.6 \%$ ), which corroborates the studies of (Silva et al., 2003) and (Santana et al.) in which the AfroCaucasians (mixed skin color) are the most common group. However, differences were found and variations were noticed in the work of (Schraiber et al.) and (Chiaperini et al.) in which Caucasian individuals prevailed.

In the 223 expert testimonies analyzed, the predominant marital status was single $(n=167 ; 74.9 \%)$. Other studies also revealed in their investigation that single individuals are the most susceptible to violence (Deslandes et al.; Rezende et al.; Garcia et al., 2008).

The city of Feira de Santana has a population of 556,642 inhabitants and is located in the largest road junction of the Brazilian North-Northeast. It is also the main town of the micro-region of north-central Bahia, composed by 24 municipalities and with a population estimated at over than 950,000 (Instituto Brasileiro de Geografia e Estatística, 2010). These characteristics probably are reflected in the fact that 223 women that have undergone forensic medical examination and participated of this study were from more than 50 different cities, especially Salvador, the state capital, and several cities in the countryside of Bahia (like São Estevão, Tanquinho and Conceição do Jacuípe) even municipalities of other states (such as Paraná, São Paulo and Sergipe).

When the item occupation of victims was analyzed, there was a significant number of students $(n=42 ; 18.8 \%)$ and maids $(n=38 ; 17 \%)$. The findings corroborate other studies that investigated violence against women, in which, this information appears between the highlighted ones (Deslandes et al.; Rezende et al.). It is also worth noting the large number of farmers $(n=20 ; 9 \%)$ among the victims - a result that reflects the economic characteristics of the Feira de Santana region and surrounding cities.

Regarding the victim's connection degree with the aggressor, the bond was reported in 105 reports, representing $47 \%$ of the total number of women that 
were subject of forensic medical examination between the years 2007 and 2011. It should be noted that this type of research is not an assignment of the forensic dentist, but of the Police Station. The "spouse / companion / husband / boyfriend" had the highest incidence as the aggressor, with $22.5 \%$, followed by "ex-spouse / ex-companion / ex-husband / ex-boyfriend", with $15.2 \%$. Despite the methodological difference in the categorization of the aggressor, the study data are similar to those of other studies (Deslandes et al.; Schraiber et al.; Rezende et al.; Santana et al.) that confirm, as main aggressors, men with a bond or closely connected with the victim (usually husband / spouse / boyfriend / companion or ex-husband / ex-spouse / exboyfriend / ex-companion).

An important variable studied here was the instrument used to cause harm. In this aspect, the vast majority of instruments used were of a blunt nature $(n=$ 203; $91 \%$ ), a result of most cases of aggression that, preferably, hit the face. Other relevant studies show similar results (Nedel et al.; Garcia et al.).

The most common types of evident injuries were edema, dental fractures, dental dislocation, ecchymosis, chop wound, blunt wound, incised wound and excoriation, and injuries such as hematoma, ulcers, tooth loss, bone fractures, dental avulsion, temporomandibular joint problems, mandibular deviation and dental discoloration were highlighted for being the less common types. The methodological differences between the studies did not allow a more effective comparison between them, however a consonance between some of the results found can be presumed. A study of the Oral and maxillofacial injuries in women points edema, wound and cutting, along with ecchymosis and contusion, as the most frequent ones (Rezende et al.), which is very close to the data found in this study. However there is a disagreement about the incidence of dental fractures, since the referred investigation revealed an incidence of only $2.5 \%$, and, in this study, the incidence of dental fractures is in the second place, with a significant amount $(n=54 ; 12.2 \%)$.

Regarding the location of occurrence of the aggressions and intra- and extra-oral structures, the teeth were the most affected - the same was observed by Chiaperini et al. Regarding the extra-oral regions only, the most frequently affected were buccal, malar and mandibular, which is not consistent with the data found in investigations of Garbin et al. (2006) and Silveira et al., in which prevailed the orbital and periorbital regions among the most affected.
The use of a blunt instrument was more frequent, resulting in injury to physical integrity or to the victim's health. Such information (results of the important role played by the forensic dentist, doing a good job in forensic practice) can support the development of actions and policies that combat violence in women's health and public security.

\section{CONCLUSION}

It is noteworthy that, in most cases, the injuries occurred due to aggressions and were often associated with an aggressor with close bonds to the woman who was subjected to forensic examination. However, the number of victims who mentioned their aggressor is still lower than expected. Women still have a lot of fear regarding accusations (generating underreporting), probably for two reasons: the weakness of law enforcement or the level of the bond between the characters involved, which still keeps them attached somehow.

DA SILVA, E. N.; MATOS, F. R. R. O.; PIMENTA, R. M. C.; RODRIGUES, J. L. S. D.; MARQUES, J. A. M.; MUSSE, J. D. \& PARANHOS, L. R. Perfil epidemiológico y caracterización de las lesiones orales y maxilofaciales en mujeres víctimas de violencia interpersonal. Int. J. Odontostomat., 10(1):11-16, 2016.

RESUMEN: El objetivo fue determinar el perfil epidemiológico de mujeres víctimas de violencia y las lesiones que les acometieron la región oral y maxilofacial. Se trata de un estudio sobre datos secundarios realizado a partir del análisis de 470 informes periciales de violencia doméstica contra mujeres, recopilados entre enero del 2007 a diciembre del 2011, en el área de Odontología del Instituto Médico Legal de Feira de Santana (Bahía/Brasil). La mayoría de las mujeres estudiadas eran afrocaucásicas $(72,6 \%)$, solteras $(74,9 \%)$, con un promedio de edad de 30,4 años. En relación a la localización extraoral, las regiones bucal $(51 \%)$ y orbital $(8,8 \%)$ fueron las más afectadas. Los dientes $(50,8 \%)$ y la mucosa labial (35 \%) fueron las estructuras intraorales más afectadas. En la mayoría de los casos, las lesiones estaban asociadas a un agresor con una relación cercana a las mujeres. Las lesiones más prevalentes fueron edemas, fracturas, luxación dental y equimosis. Estas hallazgos pueden colaborar en el desarrollo de acciones para combatir la violencia contra la mujer y para la seguridad pública.

PALABRAS CLAVE: violencia doméstica, violencia contra la mujer, traumatismos faciales, odontología legal. 
DA SILVA, E. N.; MATOS, F. R. R. O.; PIMENTA, R. M. C.; RODRIGUES, J. L. S. D.; MARQUES, J. A. M.; MUSSE, J. D. \& PARANHOS, L. R. Epidemiological profile and characterization of oral and maxillofacial injuries in women victims of interpersonal violence. Int. J. Odontostomat., 10(1):11-16, 2016.

\section{REFERENCES}

Câmara dos Deputados. Estatuto da Criança e do Adolescente. Lei ${ }^{\circ}$ 8069 , de 13 de julho de 1990, e legislação correlata. 9a ed. Brasília, Biblioteca Digital da Câmara dos Deputados, 2012. Available from: http://www.crianca.mppr.mp.br/arquivos/File/publi/camara/ estatuto_crianca_adolescente_9ed.pdf

Carvalho, A. C. R.; Barros, S. G.; Alves, A. C. \& Gurgel, C. A. Maustratos: estudo através da perspectiva da delegacia de proteção à criança e ao adolescente em Salvador, Bahia. Ciênc Saúde Coletiva, 14(2):539-46, 2009.

Cavalcanti, A. L. Lesões no complexo maxilofacial em vítimas de violência no ambiente escolar. Ciênc. Saúde Coletiva, 14(5):183542, 2009.

Chiaperini, A.; Bérgamo, A. L.; Bregagnolo, L. A.; Bregagnolo, J. C.; Watanabe, M. G. C. \& Silva, R. H. A. Danos bucomaxilofaciais em mulheres: registros do Instituto Médico-legal de Ribeirão Preto (SP), no período de 1998 a 2002. Rev. Odontol. Ciênc., 24(1):716, 2009.

Costa, M. C. O.; Carvalho, R. C.; Santa Bárbara, J. F. R.; Santos, C. A. S. T.; Gomes, W. A. \& Sousa, H. L. O perfil da violência contra crianças e adolescentes, segundo registros de Conselhos Tutelares: vítimas, agressores e manifestações de violência. Ciênc. Saúde Coletiva, 12(5):1129-41, 2007.

Deslandes, S. F.; Gomes, R. \& Silva, C. M. F. P. Caracterização dos casos de violência doméstica contra a mulher atendidos em dois hospitais públicos do Rio de Janeiro. Cad. Saúde Pública, 16(1):129-37, 2000.

Garbin, C. A. S.; Garbin, A. J. I.; Dossi, A. P. \& Dossi, M. O. Violência doméstica: análise das lesões em mulheres. Cad. Saúde Pública, 22(12):2567-73, 2006.

Garbin, C. A. S.; Rovida, T. A. S.; Garbin, A. J. I.; Saliba, O. \& Dossi, A. P. A importância da descrição de lesões odontológicas nos laudos médicos-legais. R. P. G. Rev. Pós-Grad., 15(1):59-64, 2008.

Garcia, M. V.; Ribeiro, L. A.; Jorge, M. T.; Pereira, G. R. \& Resende, A. P. Caracterização dos casos de violência contra a mulher atendidos em três serviços na cidade de Uberlândia, Minas Gerais, Brasil. Cad. Saúde Pública, 24(11):2551-63, 2008.

Instituto Brasileiro de Geografia e Estatística (IGBE). Primeiros Resultados do Censo demográfico 2010. Instituto Brasileiro de Geografia e Estatística, 2010. Available from: http:// www.ibge.gov.br/cidadesat/

Krause, R. G. S.; Júnior, A. N. S; Schneider, L. E.; Aguiar, R. C. \& Smidt, R. Etiologia e incidência das fraturas faciais: estudo prospectivo de 108 pacientes. Rev. Ciênc. Méd. Biol. (Salvador), 3(2):188-93, 2004.

Montovani, J. C.; Campos, L. M. P.; Gomes, M. A.; Moraes, V. R. S.; Ferreira, F. D. \& Nogueira, E. A. Etiologia e incidência das fraturas faciais em adultos e crianças: experiência em 513 casos. Rev. Bras. Otorrinolaringol., 72(2):235-41, 2006

Nedel, F.; Nedel, A. P.; Silva, R. H. A. \& Lund, R. G. Evaluation of identification cases involving forensic dentistry in the city of Pelotas, RS, Brazil, 2004-2006. Braz. J. Oral Sci., 8(1):55-8, 2009.
Ogundare, B. O.; Bonnick, A. \& Bayley, N. Pattern of mandibular fractures in an urban major trauma center. J. Oral Maxillofac. Surg., 61(6):713-8, 2003.

Reis, J. C. \& Fradique, F. S. Significações sobre causas e prevenção das doenças em jovens adultos, adultos de meia-idade e idosos. Psicol. Teor. Pesqui., 19(1):47-57, 2003.

Rezende, E. J. C.; Araújo, T. M.; Moraes, M. A. S.; Santana, J. S. S. \& Radicchi, R. Lesões buco-dentais em mulheres em situação de violência: um estudo piloto de casos periciados no IML de Belo Horizonte, MG. Rev. Bras. Epidemiol., 10(2):202-14, 2007.

Roselino, L. M. R.; Bregagnolo, L. A.; Pardinho, M. A. B. S.; Chiaperini, A.; Bérgamo, A. L.; Santi, L. N.; Bregagnolo, J. C.; Watanabe, M. G. C. \& Silva, R. H. A. Danos buco-maxilo-faciais em homens da região de Ribeirão Preto (SP) entre 1998 e 2002. Odontol. Ciênc. Saúde, 10(2):71-7, 2009.

Santana, J. L. B.; Silva, B. S.; Santos, J. C.; Andrade, P. O.; Moreno, B. L. G.; Campello, R. I. C. \& Souza, E. H. A. Lesões corporais e faciais em mulheres submetidas a exame de corpo de delito em Recife/PE, Brasil. Odontol. Clín. Cient., 10(2):133-6, 2011.

Santi, L. N; Mestriner Júnior, W. \& Nakano, A. M. S. Pesquisas sobre violência e odontologia legal: revisão da produção científica do Brasil. Rev. Odonto Ciênc., 20(49):242-4, 2005.

Schraiber, L. B.; D'Oliveira, A. F. P. L.; França-Junior, I. \& Pinho, A. A. Violência contra a mulher: estudo em uma unidade de atenção primária à saúde. Rev. Saúde Pública, 36(4):470-7, 2002.

Secretaria de Políticas de Saúde. Ministério da Saúde. Política Nacional de Redução da Morbimortalidade por Acidentes e Violência. Rev. Saúde Pública, 34(4):427-30, 2000.

Silva, F. F.; Sá, R. M. P. F. \& Paranhos, L. R. Domestic violence and the role of the dentist from the public health perspective: a review of scientific literature. Acta Bioeth., 20(1):125-33, 2014.

Silva, I. V. Violência contra mulheres: a experiência de usuárias de um serviço de urgência e emergência de Salvador, Bahia, Brasil. Cad. Saúde Pública, 19(Suppl. 2):S263-S272, 2003.

Silveira, J. L. G. C.; Mayrink, S. \& Sousa, O. B. Maus-Tratos na Infância e Adolescência: Casuística, Conhecimento e Prática de Cirurgiões-Dentistas de Blumenau-SC. Pesqui. Bras. Odontopediatria Clin. Integr., 5(2):119-26, 2005.

Wulkan, M.; Parreira Jr., J. G. \& Botter, D. A. Epidemiologia do trauma facial. Rev. Assoc. Med. Bras., 51(5):290-5, 2005.

Correspondence to:

Prof. Luiz Renato Paranhos

Professor, Department of Dentistry

Federal University of Sergipe

Jordão de Oliveira St., 996, Ap. 1402 - Bairro Atalaia

Aracaju/SE CEP: 49037-330

BRAZIL

Email: paranhos.Irp@gmail.com

Received: 16-08-2015

Accepted: $29-12-2015$ 